316. コンバクトデーライトシステムの使用経験

大阪市立大学医学部付属病院 中央放射線部 O度辺晋一, 苦松牧夫, 岸本健治, 㚼川政勝

目的 D社より発売されたデーライトシステムは、自動現像機の上にデーライトシステムが配置されており、そ の据え付け面䅞は、現在市販中のうち最小である。当施設ではコンパクトさのために㩧作室中に設置し、 よい結果を得ているので報告する。

方法 カセッテ運搬距離が短くできたことによる作業動線の比較、デイライトシステムとしての性能、自動現像 機の上配固されているための問題点、などを検討する。

結果 小型のために操作室に設置できた。このため、作業動線注端に短くなり、撮影しながらつィルムの人れ 替え、現像ができる。コンバクトさ故の問題点はなく、また自動現像機についても問題はなかった。

317. C RTモニター上に拈ける画像の周辺光の影響について

\title{
東京都立医療技術短期大学 ○細渕安弘
}

(目的)観察系における環境について科学的研究があまり行われていない。ここてC R T観察系の周辺の明

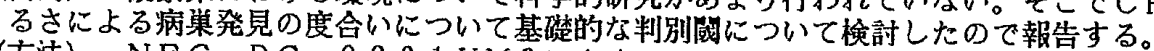

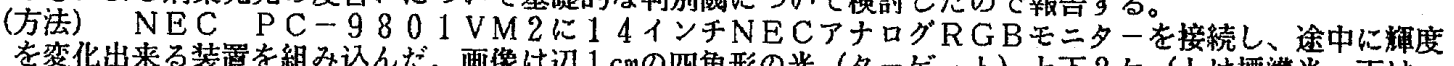

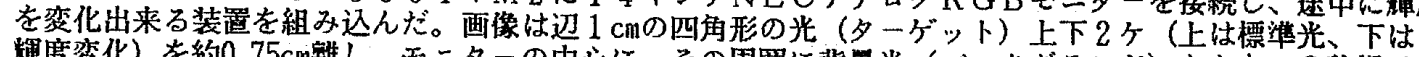
煇度変化) 約 $0.75 \mathrm{~cm}$ 離し、モニターの中心に、その周囲に背量光 (バックグラント) をともに2秒提示し その後0.5 秒休止。これを繰り返す。周辺光は、それそれ100、400 Lux で親察累を照らす。観察者は CRTより約 $40 \mathrm{~cm}$ 距離から画像を観察し、マッチング点をさがす。方法は極限法である。画像のコントラ ストを変えたものも行った。観察者は正常色視、視力1.0である。

(結果) 観察系にCRTを用いた時、周辺光は明るさの判别跑にあるすり大きな影響を与えないと思われる。

318． 心理学的手法による蕞度弁別敬の測定

愛媛大学医学部附属病院放射線部 ○大石 茂雄、伊達 卓二、吉本 政弘、川上漀炤

近年画像評洒に対するアブローチでは、物理学的特性の評洒はもとより、視覚的 (心理学的) 特性の評洒が数多く 試みられている。しかしながら、これらの評価法の中には测定の精度、再現性、定重性などの点で满足できるものは 多くない。そこで、画像の評洒に際して心理学的差異を定荲的に取り扱える测定法が不可欠のむのとなってくる。

今回取り上げた行動心理学の中の精神物理学的測定法の原理は、心理学的差巽がその背景に必ず内抱している物理 的差異を定重的に取り扱うことで理学的差異を表現していこうというものであり、画像評価法としての応用が考え られるものの一つである。

我々は、心理学的差買を定荲的に取り扱う試みとして、精神物理学的測定法のうち恒常法々呼ばれる手法を用いて、 $X$ 線画像の写真灌度并別阈を测定し、満足すべき結果を得たので報告するとともに、今後最小認識径の测定など画像 評优に斿ける心理的要因を定箽的に取り扱いうる評洒法としての可能性を検討したので併せて報告する。

319. 専門分野の違いによる、観察者群の評価の差異について

奈良県立医科大学附属病院 中央放射線部・同外んセンター O中前 光弘・吉峰 正・桝本芳文

$$
\text { 吉川 昌一・前田 要 ・宇山 茂樹 }
$$

（目的）観察者の専門分野の違いによる、胸部X線写真の評檤について比較桧討した。

（方法）異なるF i l m-Screen 系の胸部写真を数種類作成し、放射線科、胸部外科、内科の)各科所属 医師により、サーストンの一対比較法て、絴隔部、心陰影、肺野部を評洒してもらい、稳合評洒する。 そして、各診療科別に尺度值、相関係数を算出し、それそれについて比較検討する。

（結果） 観察者が所属する診療科の別により評洒が買なり、きの差異方胸部写真の評価に直接反映することが㭁か $\supset た 。$ 